\title{
Correction
}

\section{Correction to: An accurate solution for stress fields strongly varied across the adhesive thickness in soffit plate-strengthened beams}

Phe Van Pham ${ }^{1}$

Published online: 9 November 2020

(c) Springer Nature Switzerland AG 2020

\section{Correction to: SN Applied Sciences (2020) 2:1433 https://doi.org/10.1007/s42452-020-03216-w}

There was a small error in the author's affiliation in the initial online publication. The original article has been corrected.
Publisher's Note Springer Nature remains neutral with regard to jurisdictional claims in published maps and institutional affiliations.

The original article can be found online at https://doi.org/10.1007/s42452-020-03216-w.

$\triangle$ Phe Van Pham, phe.phamvan@utc.edu.vn | 'Structural Engineering, Research and Application Center for Technology in Civil Engineering and Department of Civil Engineering, University of Transport and Communications, \#3 Cau Giay, Hanoi, Vietnam. 